\title{
What Do Mobile-Connected Cambodians Do Online?
}

\section{Jayson W. Richardson}

John Nash
University of Kentucky, USA

Corresponding Author.

jayson.richardson@uky.edu

University of Kentucky, USA

john.nash@uky.edu

University of Kentucky, USA

johneric@uky.edu

Considering recent developments related to government monitoring of the internet in Cambodia and a renewed push in civil society to improve access to information for Cambodian citizens, we wondered: what do Cambodian owners of smartphones do on the internet? This article reports on how respondents use the Internet, use smartphones, perceive benefits of the Internet, and use social media. A survey was developed iteratively by the research team with ongoing support from members of the in-country team located in Phnom Penh, Cambodia. A planned missing data research design was utilized. The survey was disseminated to 35,000 Cambodia smart phone users. 429 responses were gathered on questions focusing on the personal, political, social activities on the internet. This study adds to the growing body of knowledge on how various societies are getting access to the internet and what they do when they are on the internet.

Richardson, J.W., Nash, J., Lingat, J.M. (2018). What do mobile-connected Cambodians do online? The Journal of Community Informatics, 14 (2), 85-108.

Date submitted: 2018-08-14. Date accepted: 2018-12-04.

Copyright (C), 2018 (the author as stated). Licensed under the Creative Commons AttributionNonCommercial-ShareAlike 2.5. Available at: www.ci-journal.net/index.php/ciej/article/view/1449 


\section{Introduction}

As people of the world become increasingly connected via the internet, the role smartphones play is becoming hard to ignore. In developing and emerging countries, there has been a noted rise in the number of people who access the internet via a smartphone (Pew, 2016). The Pew Research Center (2016), in a survey of 12 emerging nations in 2014 and 2015, noted significant increases in the percentage of adult internet users who reported accessing the internet several times a day (e.g., Nigeria, up 20 points; Ghana, up 19 points; and China, up 13 points).

Likewise, access to the internet by Cambodian citizens is also rapidly increasing. Estimates on the number of internet users in Cambodia as of 2012 range from 2.7 million to 3.8 million, depending on the source (Social Media Agencies Network, 2016; Telecommunications Regulator of Cambodia, 2016). At the end of the second quarter of 2015, 6,795,908 internet subscriptions (fixed lines plus mobile access) were in place (Telecommunications Regulator of Cambodia, 2016). This is an increase of three to four million subscriptions in just over two years.

This increase in subscriptions indicates a trend in the number of Cambodians who use internet-enabled smartphones. In 2013, the internet penetration rate reached $33 \%$ of the population, or roughly five million subscribers, this is up from 3.8 million subscribers the year before (Cambodian Daily, 2014). This growth has been spurred primarily by the availability of internet connected mobile phones, known as smartphones. BuddeCom (2016) reported that mobile phone penetration rates reached $167 \%$ in Cambodia as of the end of 2015. The pace of mobile subscriptions appears unabated, with 1.2 million new mobile subscribers added to the rolls in the first two quarters of 2015 alone (Telecommunication Regulator of Cambodia, 2016b).

Certain technological and language-localization advances (in this instance, Khmer) have spurred smartphone use in Cambodia. Phong and Sola (2014) noted how the creation of the Khmer operating system by the Open Institute in England, and later, the standardization of a Khmer script in the mid-2000s, allowed for the quick adoption of smartphones in Cambodia. Today, Khmer script is native on most smartphones. In their study of 2,066 Cambodians, Phong and Sola (2014) found that 93.7\% of respondents ages $15-65$, owned a phone, $100 \%$ had access to a phone, and $28.4 \%$ of those phones were smartphones. 
In light of recent developments related to government monitoring of the internet in Cambodia (Cambodian Center for Human Rights, 2014a, 2014b) and a renewed push in civil society to improve access to information for Cambodian citizens (Cambodian League for the Promotion and Defense of Human Rights, 2015), we wondered: what do Cambodian owners of smartphones do on the internet? As an avenue to reduce communication gaps and increase equitable practices, social media as accessed by smartphones in countries in transition, such as Cambodia, might provide insight to the relationship of technological advances and social progress.

\section{ICT4D and Social Media in Southeast Asia}

Cole and Crawford (2007) listed a number of examples in which social media was utilized to exercise political activism. For example, in Southeast Asia, the authors mention a specific large political movement coordinated through mobile phones and texting that influenced the resignation of Joseph Estrada, former president of the Philippines. Maftuh (2011) presented an extensive evaluation of the integration of ICTs in Southeast Asian countries. As part of a campaign from the Southeast Asian Ministers of Education Organization (SEAMEO), the organization tracked the ICT4D advancements in member countries, which were Brunei Darussalam, Cambodia, Indonesia, Lao PDR, Malaysia, Myanmar, Philippines, Singapore, Thailand, Timor Leste, and Vietnam (p. 1). The countries were categorized based on the usage level and pedagogical integration of ICT4D practices. Brunei, Malaysia, and Singapore have been found to lead the integration of ICT, with Cambodia, Myanmar, Lao PDR, and Timor Leste lacking the infrastructure and technologies for integration.

Although examples of positive uses of ICT4D and social media have been described, it would be erroneous to ignore that all types of organizations utilize these vehicles to disseminate and provide access to information, regardless of intent. Moir (2017) described the use of Islamic State in Iraq and Levant (ISIL) to mobilize their terrorist agenda in Southeast Asia. Foreign-trained fighters (FTF) from Iraq and Syria use Facebook, Telegram messenger, and extended sharing apps. Becoming wise to the negative uses of their services, these social media platforms have taken action to block activities related to terrorism. Moir painted a hopeful situation in the region, stating that

Continued cooperative efforts, such as those between governments and Islamic communities in particular, are perhaps the most important measures towards challenging the ideological potency of ISIL. On this point, Southeast Asian countries, and especially those with moderate religious constituencies, appear to be on the right track. (p. 104) 


\section{ICT4D and Social Media in Cambodia}

Researchers (Duggan, 1996; 1997; Dy \& Ninomaya, 2003; Lin, Hsieh, Yuok, Svaary, \& Sum, 2004; ) have identified Cambodia as a nation experiencing multifaceted reform and technological renaissance, with national goals to meet 21 st century demands by integrating innovative information and communication policies in educational systems. Despite this small country's transition into peace and stability in the 1990s, Cambodia consistently ranks near the bottom of different ICT metrics and indicators (CIA, 2005; Dutta, Lopez-Claros, \& Mia, 2006; MoEYS, 2004a, 2004b; World Bank, 2001 as cited by Richardson, 2010), including integration of ICT in education systems. Several barriers have been identified that corroborate these rankings (Minges \& Gray, 2002; Richardson, 2011), including outdated, scarce, and malfunctioning machines, internet and electric infrastructure limitations, and skills associated with integrating technology (i.e., language, on-going training, technical) were identified as leading barriers. Other countries share these issues, such as Ethiopia (Bass, 2011) and Zimbabwe (Bhukuvani, Zezekwa, \& Sunzuma, 2011). But, in Cambodia, these limitations are met with ambitious programming. For example, the Informatics for Rural Empowerment and Community Health (iREACH) program established hubs in rural villages equipped with wi-fi and telecommunications capabilities to increase information access and knowledge sharing. In comparison to more developed countries such as Japan, students in Cambodia have been found to hold the same beliefs regarding the positive attributes of ICT and future uses of technologies, despite the disparate country contexts and availability of technologies (Elwood \& MacLean, 2009). This promising similarity is a hopeful indicator that ICT4D in Cambodia is set for a positive growth due to the cultural capital that is associated with positive dispositions towards technology integration (Emmison \& Frow, 1998).

Social media has had an interesting reception in this religious country as issues of morality associated with an increase of tech-based access have emerged. According to a Reuters article (2006 as cited by Richardson, 2010), Prime Minister Hun Sen banned third generation mobile phones that can facilitate social media use due to unsolicited, inappropriate materials that his wife and her friends received. The Prime Minister's concern is an example of the complex views of the variety of adopters in Cambodia. Richardson (2011) described the different adoption groups in Cambodia by using Rogers's (2003) model of diffusion of innovations, finding that early adapters perceived ICT skills advantageous, whereas issues of trialability and complexity were most often discussed by late and reinvent adapters. Lastly, discontinuers and rejectors in Cambodia voiced concerns about complexity and observable results. In light of these differences, earlier work by Richardson (2009) found that demographic variable did not impact adoption rates in Cambodia. Rogers' model has been applied and produced similar recommendations for government supports in other countries, such as Saudi Arabia (Al- 
Ghatani, 2003) and South Africa (Chigona \& Licker, 2008). In addition, other countries have found that media has caused distortion in the integration of information and communication technologies, which include social media (Chigona \& Mooketsi, 2011).

A modern use of smartphones now includes social media access and connectivity. Phong and Sola (2014) found that $57.2 \%$ of the Cambodian smartphone owners used it to check Facebook. Of those who had Khmer-enabled smartphones, 95.5\% used it to check Facebook. Furthermore, Richardson, King, and Nash (2017) found that four out of five Cambodian smartphone users checked Facebook several times a day. Social Media Agencies Network (2016) reported that 23\% of the internet activity in Cambodia was conducted through a smartphone. Social Media Agencies Network also reported that as of early 2016, there were more than 1.7 million Facebook users in Cambodia and 1,100 new Cambodian Facebook users are added daily. That equates to about one new Facebook user every two minutes. Some authors have cautioned however that factors such as Cambodians having multiple Facebook accounts and Cambodians living abroad may distort these numbers (see Chak, 2014).

\section{Internet and Improving Conditions in Cambodia}

The advancements and use of ICT-specifically an open internet-in Cambodia contribute to the changing cultural, social, and political landscape of this country in transition. Marshall and Taylor (2009) recognized the potential improvements that can result from the adoption of ICT and open internet use, especially in LDCs primed for impressive advancements, such as Cambodia. According to the authors, addressing the role of ICT would "meet the demands and expectations of increasing global competition" in a variety of fields, such as accounting, agriculture, public health, and a host of other socioeconomic issues across the international setting (p. 2).

Richardson, Nash, and Flora (2014) reported that as Cambodian students increase technology use, their beliefs regarding future job opportunities and acquiring new skills increases as well. Unfortunately, the researchers identified barriers regarding this finding, stating that existing challenges to "internet accessibility could be drastically improved for the entire school system... student's fear of looking incompetent and damaging the machine by using the computer or Internet indicates a lack of hands-on experience and adequate support" (p. 73). This lack of access may contribute to the stagnant status of Cambodia as an LDC. In his review of internet usage in LDCs, Albirini (2008) concluded that "access is a crucial condition of informed citizenry, providing grounds for conscious decision-making, freedom of expression, and intellectual development" (p. 58). 
As observed in South Africa, Halse and Mallinson (2009) found that the latest generation (i.e., Generation Y) entering higher education and the labor market has changed the learning and training environments. ICT innovations and open internet access has been the norm for these students. Thus, a variety of technologies such as social networks and e-learning platforms have propelled socio-economic improvements that may not have occurred with previous generations of students and workers. This can also be seen in the post-Khmer Rouge baby-boomer (Cambodia's Millenial) generation, which Soeung (2016) believes are even better primed for technological innovations and socio-cultural and political reform. As identified by Vuth, Huor, and Than (2006), Cambodia in an ASEAN Foundation symposium, there is government interest to increase access and improve education by expanding distance learning opportunities using e-learning and ICT. At this same symposium, research was presented that directly impacts this directive-internet capabilities come with high costs and limited geographic accessibility. As a work around to attain increased access and connectivity, Cambodians use their mobile phones for a number of internet-based activities, such as accessing the World Wide Web, e-mailing, and texting. With the increased capabilities of smartphones and an aging generation primed for high use of technology, the potential for improving conditions in Cambodia seem promising.

\section{Methods}

The Cambodian Center for Independent Media (CCIM) was our partner in the survey development and dissemination. The population for this study was mobile-internetusing Cambodians. We choose to reach this population via text messages. CCIM contracted with Smart Axiata to achieve this task. At the time of survey dissemination, Smart Axiata was Cambodia's second largest mobile provider in terms of subscribers. At the time, Smart had more than five million subscribers nationwide, covering an estimated $96 \%$ of the population. ${ }^{1}$ In terms of geography, Smart provides complete or partial coverage to all of Cambodia's 25 provinces.

\section{Survey Design and Dissemination}

A survey was developed iteratively by the research team, with ongoing support from members of the CCIM team located in Phnom Penh, Cambodia, and with advice and guidance from various stakeholders. The survey was piloted in two rounds to ensure the question sets measured the intended constructs. Each pilot round included a group of participants who engaged in cognitive interviews and another group who engaged in testing the updated mobile-delivered online survey. In each round, the English survey was created, translated into Khmer, then back-translated into English.

\footnotetext{
${ }^{1} \mathrm{http}: / /$ www.axiata.com/operating/company/smart
} 
To lower the cost of data collection and reduce participant time burdens to take the survey, a planned missing data design was utilized (Graham et al, 2006). All participants were asked Z-block questions about demographics. All participants were additionally asked to complete X-block questions that focused on online freedom of expression. Ablock questions focused on internet use and access. B-block questions focused on social media use personally and around political issues. C-block questions focused on freedom of the internet and politics. Table 1 describes the three-form approach

Table 1. Overview of the study's three-form design

\begin{tabular}{|c|c|c|c|c|c|}
\hline \multirow{2}{*}{$\begin{array}{l}\text { Form } \\
\text { No. }\end{array}$} & Z-Block & X-Block & A-Block & B-Block & C-Block \\
\hline & $\begin{array}{l}5 \text { Questions } \\
\text { (Demographics) }\end{array}$ & $\begin{array}{l}5 \text { Questions } \\
\text { (Online } \\
\text { Freedom of } \\
\text { Expression) }\end{array}$ & $\begin{array}{l}7 \text { Questions } \\
\text { (internet Use } \\
\text { and Access) }\end{array}$ & $\begin{array}{l}8 \text { Questions } \\
\text { (Personal and } \\
\text { Political } \\
\text { Social Media } \\
\text { Use) }\end{array}$ & $\begin{array}{l}15 \\
\text { Questions } \\
\text { (Political } \\
\text { Freedom on } \\
\text { the internet) }\end{array}$ \\
\hline 1 & Yes & Yes & Yes & Yes & No \\
\hline 2 & Yes & Yes & Yes & No & Yes \\
\hline 3 & Yes & Yes & No & Yes & Yes \\
\hline
\end{tabular}

The current research focuses solely on a subset of the broad survey approach described above, reporting only on Forms 1 and 2 of Z-Block and A-Block (demographics and internet use and access). A link to an online survey, hosted on the Survey Monkey system, was sent via a bulk SMS containing a link to the survey to Smart Axiata subscribers who had an internet-enabled smartphone. The SMS was disseminated on March 12, 2015, to 35,000 randomly chosen mobile smartphone users. From March 12-16, 2015, 884 responses were received from those who accessed the survey. A follow-up SMS also containing a link to the survey URL was sent on March 17, 2015, to 32,375 of the initial recipients who had not yet completed the survey. From March 17-18, 2015, an additional 243 responses were received. In total, 895 Cambodians participated in the study. ${ }^{2}$ Of that number 464 completed Block A, 429, completed Block B, and 429 completed Block C. Response rates per form are reported in Table 2.

2 The survey invitation was in Khmer. From that invitation, respondents could opt to take the survey in English. This technique caused day-to-day response rates to be higher than the total number of respondents due to English respondents being initially counted twice (once on the language preference question of the initial Khmer survey and once on the actual completed English survey). 
Table 2. Survey response rate by block

\begin{tabular}{llll}
\hline Block & Surveys Started & Surveys Completed & $\%$ Complete \\
\hline A & 530 & 464 & $85 \%$ \\
B & 507 & 429 & $88 \%$ \\
C & 531 & 429 & $81 \%$ \\
\hline
\end{tabular}

Table 3 details the response times by language. The English version took respondents an average of just under 18 minutes to complete, while the Khmer version took respondents an average of 29 minutes to complete.

Table 3. Survey response times

\begin{tabular}{ccc}
\hline Response Time & English & Khmer \\
\hline AB Blocks & $0: 13: 38$ & $0: 22: 36$ \\
AC Blocks & $0: 16: 39$ & $0: 29: 13$ \\
BC Blocks & $0: 17: 52$ & $0: 20: 14$ \\
\hline
\end{tabular}

*19 respondents removed because they remained active in the survey for multiple days.

\section{Results}

\section{Demographics}

\section{Linguistic preferences}

Roughly $75 \%$ of respondents selected to take the survey in Khmer. The remaining $25 \%$ chose to be redirected to an English-language version of the same survey, which featured an additional question confirming the respondent's Cambodian citizenship before starting the survey questions. Non-citizens were disqualified from participation.

Age

Respondents' average age was approximately 25 years old. This finding is in line with national data that indicates that the country's population is relatively young, with about $60 \%$ of Cambodians under the age of 30 . 


\section{Gender}

632 respondents $(74.9 \%)$ were male, whereas $186(22 \%)$ were female. One percent indicated "Other" and $2 \%$ preferred not to answer.

\section{Place of residence}

The survey gathered respondents from 22 of the country's 25 provinces (missing were Kep, Mondulkiri, and Stung Treng). Notably, 66.6\% of respondents were from Phnom Penh where mobile phones are widespread. Other provinces drawing substantial amounts of respondents, including Siem Reap (6.2\%), have urban areas or, in the case of Kandal (5.9\%), are located near a large city (i.e., the capitol city of Phnom Penh).

Table 4. In which language would you like to take this survey?

\begin{tabular}{lll}
\hline Language & $\mathrm{N}$ & Percent \\
\hline Khmer & 735 & 74.8 \\
\hline English & 248 & 25.2 \\
\hline Total & 983 & 100.0 \\
\hline
\end{tabular}


Table 5. In which province do you currently live?

\begin{tabular}{|c|c|c|}
\hline Province & $\mathrm{N}$ & Percent \\
\hline Phnom Penh & 552 & 66.6 \\
\hline Banteay Meanchey & 3 & .4 \\
\hline Battambang & 12 & 1.4 \\
\hline Kampong Cham & 31 & 3.7 \\
\hline Kampong Chhnang & 6 & .7 \\
\hline Kampong Speu & 18 & 2.2 \\
\hline Kampong Thom & 8 & 1.0 \\
\hline Kampot & 13 & 1.6 \\
\hline Kandal & 49 & 5.9 \\
\hline Koh Kong & 9 & 1.1 \\
\hline Kratie & 5 & .6 \\
\hline Oddar Meanchey & 3 & .4 \\
\hline Pailin & 1 & .1 \\
\hline Preah Sihanouk & 12 & 1.4 \\
\hline Preah Vihear & 2 & .2 \\
\hline Pursat & 7 & .8 \\
\hline Prey Veng & 12 & 1.4 \\
\hline Ratanakiri & 3 & .4 \\
\hline Siem Reap & 51 & 6.2 \\
\hline Svay Rieng & 8 & 1.0 \\
\hline Takeo & 18 & 2.2 \\
\hline Tbong Khmum & 6 & .7 \\
\hline
\end{tabular}




\section{Education}

Survey respondents were better educated than the general population with just over $55 \%$ of respondents having completed their bachelor's degree, and with $25.5 \%$ having earned their high school diploma. This represents a considerably higher level of education than the general population, wherein only $39.4 \%$ of male and $35.8 \%$ of female students enroll in secondary school, according to UNICEF.

Table 6. What is the highest level of education you have completed?

\begin{tabular}{lll}
\hline Type & $\mathrm{N}$ & Percent \\
\hline Primary school & 17 & 2.1 \\
\hline Secondary school & 74 & 9.0 \\
\hline High school diploma & 210 & 25.5 \\
\hline Bachelor's degree & 455 & 55.2 \\
\hline Graduate degree & 69 & 8.4 \\
\hline
\end{tabular}

\section{Income}

The majority of respondents $(63.1 \%)$ made less than \$500 USD per month, with the largest single percentage of respondents $(35.2 \%)$ indicating that their personal income was between $\$ 100$ and $\$ 299$ USD per month. $25.5 \%$ of respondents chose not to answer this question. 
Table 7. What is your personal monthly income?

\begin{tabular}{lll}
\hline & N & Percent \\
\hline Less than \$100 USD & 95 & 11.6 \\
\$100 to \$299 USD & 289 & 35.2 \\
\$300 to \$499 USD & 134 & 16.3 \\
\$500 to \$999 USD & 57 & 7.0 \\
\$1,000 to \$2,999 USD & 27 & 3.3 \\
\$3,000 to \$4,999 USD & 2 & .2 \\
\$5,000 USD or more & 7 & .9 \\
Prefer not to answer & 209 & 25.5 \\
\hline
\end{tabular}

\section{Use of ICT Devices}

\section{Smartphones}

Most respondents (97.5\%) reported using their smartphone to access the internet at least occasionally, with $77.6 \%$ indicating that their smartphone is their preferred device for accessing the internet. This confirms statements from the Kingdom's telecom regulator in March 2015 which claimed that up to $98 \%$ of the country's internet traffic originates from smartphones.

Table 8. Please choose the statement that best describes your use of your smartphone

\begin{tabular}{lll}
\hline Type of use & $\mathrm{N}$ & Percent \\
\hline I never use this device to access the internet & 13 & 2.5 \\
$\begin{array}{l}\text { I only use this device to access the internet if another is } \\
\text { not available }\end{array}$ & 102 & 19.8 \\
\begin{tabular}{l} 
This is my preferred device for accessing the internet \\
\hline
\end{tabular} & 399 & 77.6 \\
\hline
\end{tabular}




\section{Laptop computers}

Ninety percent of respondents reported using their laptop computer to access the internet at least occasionally. However, only $47.2 \%$ identified the laptop as their preferred device for accessing the internet. About $42 \%$ reported they only use their laptop if another device is not available. Additionally, 10\% of respondents reported they never use their laptop to access the internet at all.

Table 9. Please choose the statement that best describes your use of your laptop computer

\begin{tabular}{lll}
\hline Primary use of laptop computer & N & Percent \\
\hline I never use this device to access the internet & 51 & 10.0 \\
$\begin{array}{l}\text { I only use this device to access the internet if another is } \\
\text { not available }\end{array}$ & 219 & 42.9 \\
$\begin{array}{l}\text { This is my preferred device for accessing the internet } \\
\text { 241 }\end{array}$ & 47.2 \\
\hline
\end{tabular}

\section{Desktop computers}

A desktop computer was the least popular means of accessing the internet among survey respondents. Around $27 \%$ of respondents reporting that they never use a desktop computer to access the internet and another $44.7 \%$ reported that they only use a desktop computer if another internet-enabled device is not available.

Table 10. Please choose the statement that best describes your use of your desktop computer

\begin{tabular}{lll}
\hline & N & Percent \\
\hline I never use this device to access the internet & 138 & 27.2 \\
$\begin{array}{l}\text { I only use this device to access the internet if another is } \\
\text { not available }\end{array}$ & 227 & 44.7 \\
\begin{tabular}{l} 
This is my preferred device for accessing the internet \\
\hline
\end{tabular}
\end{tabular}




\section{Frequency of Internet Access}

Most respondents (91.2\%) reported that they access the internet at least once per day, with almost $66 \%$ of respondents reporting accessing the internet "continuously" through pushout (i.e., automated) updates to their phones. This data corresponds with the large number of respondents $(97.5 \%)$ reporting they prefer to access the internet via a smartphone in Table 10.

Table 11. Overall, how often do you access the internet (from any device)?

\begin{tabular}{lll}
\hline Amount & $\mathrm{N}$ & Percent \\
\hline Infrequently & 11 & 2.2 \\
Weekly & 8 & 1.6 \\
2-4 times per week & 25 & 5.0 \\
More than once per day & 127 & 25.3 \\
Continuously & 331 & 65.9 \\
\hline
\end{tabular}

\section{Expenditures on Internet Access}

Despite frequent internet use, as shown in Table 13, the majority of respondents $(60.9 \%)$ spend less than $\$ 10$ per month to access the internet. Only $7.2 \%$ of respondents reported paying \$20 USD or more per month. Given the high rate of smartphone use among survey respondents, the low expenditures on internet data can likely be attributed to Cambodia's highly competitive telecommunications market.

Table 12 . How much do you normally pay to access the internet?

\begin{tabular}{lll}
\hline Amount & $\mathrm{N}$ & Percent \\
\hline Less than \$5 USD per month & 144 & 28.9 \\
\$5 to \$9 USD per month & 160 & 32.1 \\
\$10 to \$14 USD per month & 104 & 20.8 \\
\$15 to \$19 USD per month & 55 & 11.0 \\
\$20 to \$49 USD per month & 26 & 5.2 \\
\$50 USD or more per month & 10 & 2.0 \\
\hline
\end{tabular}




\section{Adoption of the Internet}

A few respondents were early adopters of regular internet use. However, the majority started regularly using the internet after 2005, with significant year-by-year increases in the number of adopters seen since 2010 .

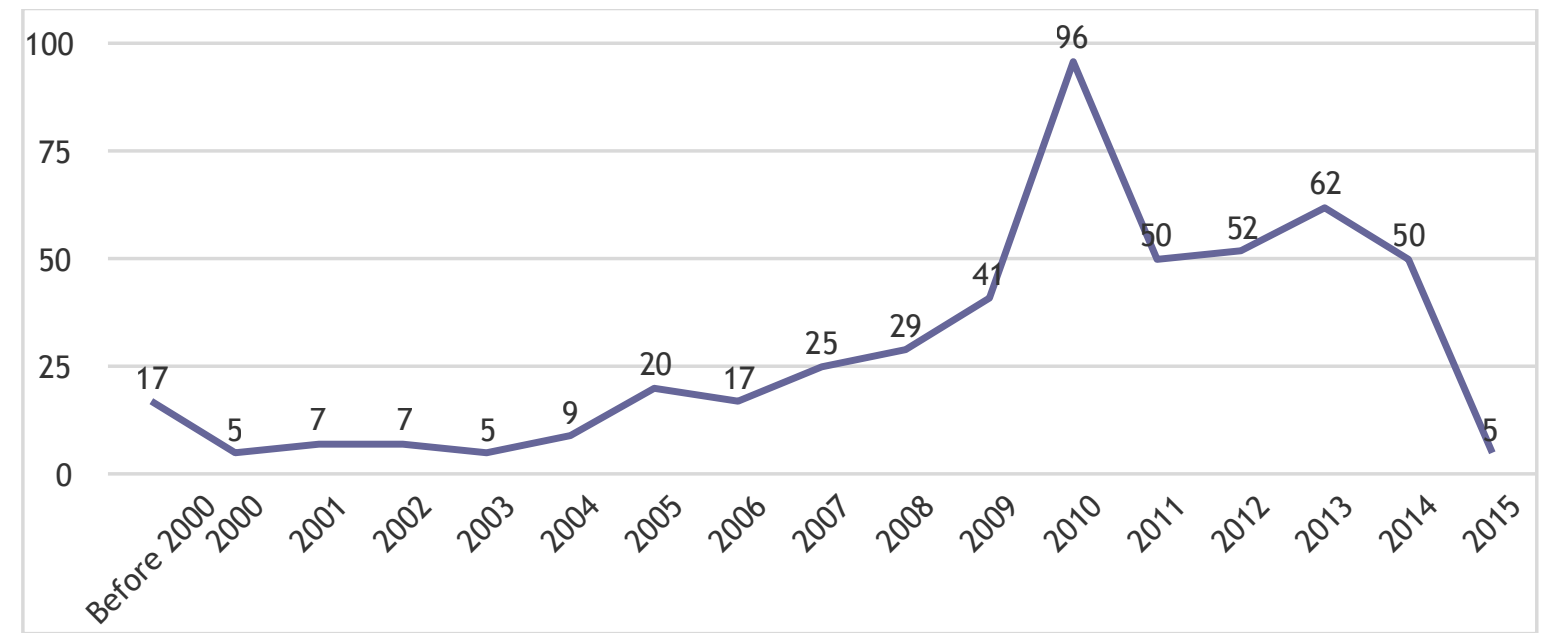

Figure 1. Year in which respondents report using the internet regularly.

\section{Perceived Benefits of Internet Use}

The following data tables report findings about how Cambodians use the internet. Tables 15 to 17 demonstrate that respondents find the internet useful in their daily lives in a number of ways, including for improving performance in their jobs (78.8\%), use in their studies (73.7\%), for accessing news (75\%), for entertainment $(66.1 \%)$, and for connecting with friends and family $(69.2 \%)$. Fewer respondents however reported that the internet was useful for e-commerce.

Table 13. Does the internet make your job easier or contribute to your professional development? and Does the internet help in your education and studies?

\begin{tabular}{lllll}
\hline & $\begin{array}{l}\text { Does the internet make your job } \\
\text { easier or contribute to professional } \\
\text { development? }\end{array}$ & $\begin{array}{l}\text { Does the internet help in your } \\
\text { education and studies? }\end{array}$ \\
\hline N & Percent & N & Percent \\
\hline Yes & 387 & 78.8 & 362 & 73.7 \\
No & 104 & 21.2 & 129 & 26.3 \\
\hline
\end{tabular}

Many respondents $(75.3 \%)$ said the internet is useful in providing them with news and information that they cannot find offline in the country's mainstream media. Notably, only $33.7 \%$ of respondents said the internet makes it easy for them to shop online. Only $29 \%$ of respondents reported that the internet made it easy for them to manage their finances online via online banking or bill pay. 


\section{Social Media Use}

The overwhelming majority of respondents reported holding accounts on three or more social media platforms. Remarkably, 99.2\% (all but four respondents) reported having a Facebook account, and 81.6\% reported using Facebook several times per day. This data reflects the growing influence of Facebook in Cambodian society.

Though not as popular as Facebook, Google+ demonstrated a wide following among survey respondents, with $88.5 \%$ of respondents reporting that they have an account with the social media network. However, Google+ users were less likely to check their accounts as often as Facebook users, with only $28.2 \%$ of respondents reporting that they use their Google+ account multiple times per day.

The messaging network Line also proved popular among survey respondents, with $84.7 \%$ of respondents reporting having a Line account. Though not as active as Facebook users, Line account holders outpaced Google+ users in terms of use, with $31.2 \%$ reporting logging onto Line multiple times per day.

Roughly half of respondents (49.3\%) reported holding an Instagram account. However, as with Google+ and Line, Instagram account holders were substantially less active than Facebook account holders, with only $12.4 \%$ reporting accessing their Instagram account several times per day.

Twitter was by far the least popular social media platform. Only $32.4 \%$ of respondents reported having a Twitter account. Moreover, respondents who did have Twitter accounts used it less frequently than Facebook, Google+ or Line users, with the majority of account holders reporting that they used Twitter only "every few weeks or less." 
Table 14. How often do you use the following social media platforms?

\begin{tabular}{lccccccccccc} 
& Facebook & \multicolumn{2}{c}{ Google+ } & Line & & \multicolumn{2}{c}{ Instagram } & \multicolumn{2}{l}{ Twitter } \\
& $\mathrm{N}$ & $\%$ & $\mathrm{~N}$ & $\%$ & $\mathrm{~N}$ & $\%$ & $\mathrm{~N}$ & $\%$ & $\mathrm{~N}$ & $\%$ \\
No account & 4 & 0.8 & 54 & 11.5 & 74 & 15.3 & 246 & 50.7 & 330 & 67.6 \\
$\begin{array}{l}\text { Every few weeks or } \\
\text { less }\end{array}$ & 2 & 0.4 & 77 & 16.3 & 69 & 14.3 & 66 & 13.6 & 79 & 16.2 \\
1-2 days a week & 4 & 0.8 & 52 & 11.0 & 55 & 11.4 & 28 & 5.8 & 20 & 4.1 \\
3-4 days a week & 13 & 2.7 & 59 & 12.5 & 47 & 9.7 & 38 & 7.8 & 22 & 4.5 \\
About once per day & 66 & 13.7 & 96 & 20.4 & 88 & 18.2 & 47 & 9.7 & 28 & 5.7 \\
Several times per day & 394 & 81.6 & 133 & 28.2 & 151 & 31.2 & 60 & 12.4 & 9 & 1.8 \\
\hline
\end{tabular}

The researchers created a social media use score, derived from an average of the reported use of all social media channels covered in the survey (e.g., Facebook, Google+, Line, Twitter, and Instagram). The social media scores range from zero (no use on any channel) to five (use of all channels several times a day). The average social media score across all respondents was 2.57 , suggesting that, on average, users engage in one or more social media channels 3-4 days a week. There is no statistically significant difference in social media use between residents who live in urban provinces versus those who live in rural provinces.

\section{Limitations}

The study has two noted limitations. First, Cambodians often have more than one mobile number and more than one mobile data subscription. Thus, we are uncertain how many of the Smart subscribers targeted in this study were duplicates. Second, participants had to use their own data to participate in the study. This may have limited the number of participants willing to participate in the study.

\section{Conclusion}

We examined devices used, their frequency of use, expenditures by users, the perceived benefits of the internet, and users' social media use. We found that in terms of devices used to access to the internet, respondents overwhelmingly rely first on a smartphone (78\%). They report using a laptop to access the internet occasionally, but only about half $(47 \%)$ use it as a preferred device. 
Globally, $43 \%$ of phone users say they own a smartphone (Pew, 2016). In 2016, 48\% of Cambodians own at least one smartphone, more than doubling the penetration rate of 2015. This number is even greater in urban settings (Asia Foundation, 2016). By design, our sample was limited to smartphone users, so it follows that the device of choice for accessing the internet was a smartphone. Pew (2016) noted that the share of smartphone owners in developing countries has increased dramatically since 2013. We would expect more Cambodians to own smartphones in the coming year, and thus their use as a primary access point to the internet will follow.

In the current study, most respondents (91\%) reported they access the internet at least once per day. Two thirds state they access the internet continuously via content pushed to their smartphones. In contrast, Pew (2016) reported that "[r] oughly three-quarters of adult internet users across... 40 countries [stating] they use the internet at least once a day, with majorities in many countries saying that they access the web 'several times a day"' (p. 5).

Our respondents reported finding the internet useful in their daily lives in a number of ways, including for improving their performance in their jobs $(78.8 \%)$, education and studies (73.7\%), and for connecting with friends and family (69.2\%). However, fewer respondents felt the internet made it easy for them to shop online (33\%) or bank online (29\%) and two-thirds (66\%) stated the internet does not serve as a mechanism for entertainment. In terms of accessing news and information, $75 \%$ of the respondents felt the internet provided them with access to news and information they could not find elsewhere.

Other reports state only $8 \%$ of Cambodians use the internet to shop (Hale, 2016), a finding which is not inconsistent with our findings. We asked whether respondents felt the internet made it easier to shop. As to how many of them actually do, we cannot say from our study. Some of our findings in this area appear consistent with findings by other researchers on Cambodian online habits. For example, Cambodians had a positive response to reading or watching content from ads on social media $(59 \%)$, and were second to Brazil in being open to sharing information about brands if offered a reward (Kantar TNS, 2016). 
Cambodian smartphone users have a heavy social media diet. All but four respondents (99\%) reported having a Facebook account, and 82\% reported using Facebook several times per day. $88.5 \%$ of respondents reporting that they have a Google+ account, but only $28 \%$ check it multiple times per day. The messaging network Line also proved popular among survey respondents with $31 \%$ of respondents logging in multiple times per day. Roughly half of respondents (49.3\%) reported holding an Instagram account. The high penetration of Facebook among our respondents is not surprising in light of other reports. According to Social, a social media agency in Singapore that tracks digital indicators in Cambodia, the number of Facebook users is 3.4 million (Tan, 2016), fueled in large part by the high use of mobile connections.

In sum, most of the Cambodia internet connected mobile users in this study felt that the internet is a mechanism to improve personal, professional, and civil duties. Only an open and unmonitored internet will allow citizens to express themselves freely and use the internet as tool to stay informed and engage in the world, their nation, and their culture. This study thus aimed to understand how Cambodian citizens play an active role in their online society.

\section{Implications}

As Cambodians integrate the use of smartphones into their daily lives and changing culture, modern uses are constantly developing. Policies that support the productive and safe use of mobile phones can usher a new era of connectivity for Cambodians. Learning from early adapters of mobile-based technologies, Cambodian policies can reflect the social advances that technology and innovation can facilitate.

Research on the use of mobile devices by Cambodians can focus on further mining the individual utility of this growing practice. Questions remain as to particular benefits as well as drawbacks of mobile connectivity. Further explorations on how Cambodians utilize social media platforms, such as Facebook, would provide insight on the popularity of the site. For example, is Facebook used to meet new people beyond the physical borders of the user or is it a means of direct messaging to other users with the same access.

\section{References}

Abbott, J. P. (2011). Cacophony or empowerment? Analysing the impact of new information communication technologies and new social media in Southeast Asia. Journal of Current Southeast Asian Affairs, 30, 3-31.

Adebowale, O. F., Adewale, I. A., \& Oyeniran, F. M. (2010). Computer interests, approval and confidence of secondary school students in three selected local governments of Lagos State (Nigeria): Implications for global computerization. 
International Journal of Education and Development Using Information and Communications Technology, 6, 40-52.

Adam, M. S., \& Urquhart, C. (2007). IT capacity building in developing countries: A model of the Maldivian tourism sector. Information Technology for Development, 13, 315-355.

Afari-Kumah, E., \& Achampong, A. K. (2010). Modeling computer usage intention of tertiary students in a developing country through the technology acceptance model. International Journal of Education and Development Using Information and Communications Technology, 6, x-x.

Akpan, P. I. (2003). Basic-needs to globalization: Are ICTs the missing link? Information Technology for Development, 10, 261-274.

Al-Ghatani, S. S. (2003). Computer technology adoption in Saudi Arabia: Correlates of perceived innovation attributes. Information Technology for Development, 10, 57-69.

Albirini, A. (2008). The internet in developing countries: A medium of economic, cultural and political domination. International Journal of Education and Development Using Information and Communication Technology, 4, 49-65.

Ale, K., \& Chib, A. (2011). Community factors in technology adoption in primary education: Perspectives from Rural India. Information Technologies \& International Development, 7, 53-68.

Andersson, A. (2008). Seven major challenges for e-learning in developing countries:

Case study for eBIT, Sri Lanka. International Journal of Education and Development Using Information and Communications Technology, 4, 45-62.

Angus, L., Snyder, I., \& Sutherland-Smith, W. (2004). ICT and educational (dis)advantage: Families, computers and contemporary social and educational inequalities. British Journal of Sociology of Education, 25, 3-18.

Avegrou, C. (2010). Discourses on ICT and development. Information Technologies \& International Development, 37, 1-18.

Baliamoune-Lutz, M. (2003). An analysis of the determinants and effects of ICT diffusion in developing countries. Information Technology for Development, 10, 151-169.

Bass, J. M. (2011). An early-stage ICT maturity model derived from Ethiopian education institutions. International Journal of Education and Development Using Information and Communication Technology, 7, 5-25.

Best, M. L. (2010). Understanding our knowledge gaps: Or, do we have an ICT4D

field? And do we want one? Information Technologies and International Development, 6, 49-52.

Bhukuvani, C., Zezekwa, N., \& Sunzuma, G. (2011). Students' preparedness to integrate information and communication technology tools and resources for the learning of organic chemistry concepts in the district of Masvingo, Zimbabwe. International Journal of Education and Development Using Information and Communication Technology, 7, 27-37.

Cambodia Daily (2014, February 3). CNRP distances itself from threatened social media activist. Retrieved from https://www.cambodiadaily.com/archives/cnrp-distancesitself-from-threatened-social-media-activist-51218/

Cambodian Center for Human Rights (2014a). Cybercrimes laws: Tools for protecting or restricting freedom of expression? Retrieved from http://www.cchrcambodia.org/ index old.php?url=media/media.php\&p=analysis detail.php\&anid=51\&id=5

Cambodian Center for Human Rights (2014b). The criminalization of defamation and freedom of expression in Cambodia. Retrieved from http://cchrcambodia.org/admin/ $\mathrm{m}$ e d i a / a n a 1 y s i s / a n a 1 y s i s / e n g 1 i s h / 2014_05_27_CCHR_Briefing_Note_Defamation_in_Cambodia_(ENG).pdf

Cambodian League for the Promotion and Defense of Human Rights (LICADHO) (2015, May). Going offline? The threat to Cambodia's newfound internet freedoms. Retrieved from https://www.licadho-cambodia.org/reports/files/205LICADHOReport- 
GoingOfflineinternetFreedoms-English.pdfChak, S. (2014). New information and communication technologies' influence on activism in Cambodia. International Journal on Human Rights, 20, 437-447.

Chigona, A., Chigona, W., Kayongo, P., \& Kausa, M. (2010). An empirical survey on domestication of ICT in schools in disadvantaged communities in South Africa. International Journal of Education and Development Using Information and Communications Technology, 6, 21-32.

Chigona, W., \& Licker, P. (2008). Using diffusion of innovations framework to explain communal computing facilities adoption among the urban poor. Information Technologies and International Development, 4, 57-73.

Chigona, W., \& Mooketsi, B. (2011). In the eyes of the media: Discourse of an ICT4D project in a developing country. Electronic Journal in Information Systems in Developing Countries, 46, 1-6.

Central Intelligence Agency. (2005). The world factbook 2005. Washington, DC: Author.

Cole, R., \& Crawford, T. (2007, June). Building peace through information and communications technologies. Idealware. Retrieved from http://www.idealware.org/ printable.php?page=/articles/peace_through_ICTs.php

Duggan, S. J. (1996). Education, teacher training, and prospects for economic recovery in Cambodia. Comparative Education, 32, 361-375.

Duggan, S. J. (1997). The role of international organisations in the financing of higher education in Cambodia. Higher Education, 34, 1-22.

Dutta, S., Lopez-Claros, A., \& Mia, I. (Eds.). (20060. The global competitiveness report 2006-2007: Leveraging ICT for development (5th Ed.). Basingstoke, UK: Palgrave.

Dy, S. S., \& Ninomaya, A. (2003). Basic education in Cambodia: The impact of UNESCO on policies in the 1990s. Education Policy Analysis Archives, 11, 1-21.

Elwood. J., \& MacLean, G. (2009). ICT usage and students perceptions in Cambodia and Japan. International Journal of Emerging Technologies \& Society, 7, 66-82.

Emmison, M., \& Frow, J. (1998). Information technology as cultural capital. Australian Universities Review, 1, 41-45.

Fan, A. (2010). The readiness of schools of Macao to integrate IT in education and the extent of actual IT integration. International Journal of Education and Development Using Information and Communication Technology, 6, 52-63.

Flor, A. (2008). A policy and planning framework on information and communication technology for basic education in the Philippines. International Journal of Education and Development Using Information and Communication Technology, 4, 19-44.

Frohlich, D. M., Bhat, R., Jones, M., Lalmas, M., Frank, M., Rachovides, D., Tucker, R., \& Riga, K. (2009). Democracy, design, and development in community content creation: Lessons from the StoryBank project. Information Technologies and International Development, 5, 19-35.

Galperin, H. (2010). Goodbye digital divide, hello digital confusion? A critical embrace of the emerging IC4TD consensus. Information Technologies and International Development, 6, 53-55.

Govindaraju, P., \& Mabel, M. M. (2010). The status of information and communication technology in a coastal village: A case study. International Journal of Education and Development Using Information and Communication Technology, 6, x-x.

Graham, J. W., Taylor, B. J., Olchowski, A. E., \& Cumsille, P. E. (2006). Planned missing data designs in psychological research. Psychological Methods, 11(4), 323-343.

Hale, E. (2016). Cambodia will be Asia's next online shopping battleground. Retrieved from https://www.forbes.com/sites/erinhale/2016/11/10/cambodia-will-be-asias-next-onlineshopping-battleground/\#45b1 e5ee33bd

Halse, M. L., \& Mallinson, B.J. (2009). Investigating popular Internet applications as supporting e-learning technologies for teaching and learning with Generation Y. 
International Journal of Education and Development Using Information and Communication Technology, 5, 58-71.

Heeks, R. (2009). Theorizing ICT4D research. Information Technologies and International Development, 3, 1-4.

Kabilan, M. K., \& Rajab, B. M. (2010). The utilization of the internet by Palestinian English language teachers focusing on uses, practices and barriers and overall contribution to professional development. International Journal of Education and Development Using Information and Communication Technology, 6, 56-72.

Kantar TNS (2016). Connected Life. Retrieved from http://connectedlife.tnsglobal.com/

Kenny, C. (2002). Information and communication technologies for direct poverty alleviation: costs and benefits. Development Policy Review, 20, 141-157.

Kling, R. (2000). Learning about information technologies and social change: the contribution of social informatics. The Information Society, 16, 1-37.

Lim, M. (2016) Sweeping the unclean: Social media and the Bersih electoral reform movement in Malaysia. Global media Journal, 14, 1-10.

Lin, C., Hsieh, H., Yuok, N., Svaary, C., \& Sum, V. (2004). Evaluating the competitiveness of least-developed countries - the example of Cambodia. Asia Pacific Management Review, 9, 205-277.

Maftuh, B. (2011, February). Status of ICT integration in education in Southeast Asian countries. Paper presentation at Tsukuba International Conference: Innovation of Classroom Teaching and Learning through Lesson Study, Tsukuba University, Japan.

Moir, N. L. (2017). ISIL radicalization, recruitment, and social media operations in Indonesia, Malaysia, and the Philippines. PRISM, 7, 91-107.

Mariscal, J., Gil-Garcia, J. R., Aldama-Nalda, A., (2011). Policies on access to information technologies: The case of e-Mexico. Information Technologies and International Development, 7, 1-16.

Mariscal, J., Hernando Gutierrez, L., \& Botelho, A. J. J. (2009). Employment and youth inclusion into the labor force via training in information and communication technologies (ICTs): The cases of Brazil, Colombia, and Mexico. Information Technologies and International Development, 5, 19-30.

Marshall, S., \& Taylor, W. (2009). Editorial: Potential and challenges in the use and adoption of ICT. International Journal of Education and Development Using Information and Communication Technology, 5, 2-5.

Pew Research Center (2016). Smartphone ownership and internet usage continues to climb in emerging economies. Retrieved from http://www.pewglobal.org/files/2016/02/ pew_research_center_global_technology_report final_february_22_2016.pdf

Pew Research Center (2015). Internet seen as positive influence on education but negative influence on morality in emerging and developing nations Retrieved from http:// www.pewglobal.org/files/2015/03/Pew-Research-Center-Technology-Report-FINALMarch-19-20151.pdf

Mentealegre, R. (1999). A case for more case study research in the implementation of Information Technology in less-developed countries. Information Technology for Development, 8, 199-207.

Minges, M., \& Gray, V. (2002). Internet on the Mekong: Lao PDR case study. ITU Geneva. Retrieved from: http://www.itu.int/ITU-D/ict/cs/

Ministry of Education, Youth and Sport. (2004a). Education strategic plan 2004/08. Retrieved on June 21, 2005 from http://www.MOEYS.gov.kh/ education_reform_in_cambodia/esp2004-2008/ESP200408/ESP200408.pdf.

Ministry of Education, Youth and Sport. (2004b). Policy and strategies of information and communication technology in education in Cambodia. Phnom Penh, Cambodia: Author.

Parmar, V. (2009). A multidisciplinary approach to ICT development. Information Technologies and International Development, 5, 89-96. 
Phong, K., \& Sola, J. (2014). Mobile phones in Cambodia. Open Institute and Asia Foundation: Phnom Penh, Cambodia.

Phong, K., Srou, L., \& Sola, J. (2016). Mobile phones and internet use in Cambodia. Phnom Penh, Cambodia: Open Institute, USAID's Development Innovations and Asia Foundation.

Ramos, A. J., Nangit, G., Ranga, A. I., \& Triñona, J. (2007). ICT-enabled distance education in community development in the Philippines. Distance Education, 28, 213-229.

Rassameethes, B. (2012). Analysis and integration of Thailand ICT master plan. International Journal of Synergy and Research, 1, 77-90.

Richardson, J. W. (2008). ICT in education reform in Cambodia: Problems, politics, and policies impacting implementation. Information Technologies and International Development, 4, 67-82.

Richardson, J. W. (2009). The diffusion of technology adoption in Cambodia: The test of a theory. International Journal of Education and Development Using ICT, 5(3), 157-171.

Richardson, J. W. (2010). Case study of technology integration in Cambodia. In W.

Kinuthia, \& S. Marshall (Eds.), Educational Technology in Practice (113-124). Charlotte, NC: Informational Age Publishing, Inc.

Richardson, J. W. (2011). Challenges of adopting the use of technology in less developed countries: The case of Cambodia. Comparative Education, 55, 8-29.

Richardson, J. W., Nash, J. B., \& King, A. (2017). Perceptions of online political participation and freedom of expression: An exploratory study in Cambodia. Information Technologies \& International Development, 13, 122-137.

Richardson, J. W., Nash, J., \& Flora, K. (2014). Unsystematic technology adoption in Cambodia: Students' perceptions of computer and internet use. International Journal of Education and Development Using Information and Communication Technology, 10(2), 63-76.

Rogers, E. M. (2003). Diffusion of Innovations. $5^{\text {th }}$ ed. New York, NY: Free Press.

Spence, M. (2010). Some thoughts on ICT and growth. Information Technologies and International Development, 6, 5-9.

Spence, M., \& Smith, M. L. (2010). ICT, development, and poverty reduction: Five emerging stories. Information Technologies and International Development, 6, 11-17.

Social Media Agencies Network (2016). In Cambodia. Retrieved from http://www.socialmediacambodia.com/

Soeung, S. (2016). Cambodia in 2015: Accommodating generational change. Southeast Asian Affairs, 110-127.

Tan, D. (2016). Cambodia's digital statistics 2016. Retrieved from http://geeksincambodia.com/ cambodias-digital-statistics-2016/

Telecommunications Regulator of Cambodia (2016). Telecom statistics. Retrieved from http://www.trc.gov.kh/

Tolani-Brown, N., McCormac, M., \& Zimmermann, R. (2009). An analysis of the research and impact of ICT in education in developing country contexts. Journal of Education for International Development, 4, 1-12.

Tongia, R., \& Subrahmanian, E. (2006). Information and communications technology for development (ICT4D) - A design challenge. Retrieved from: http://repository.cmu.edu/ epp/119

Vuth, D., Huor, C. S., \& Than, C. C. (2006, May). Best practices for capacity-building

in Cambodian distance education. Paper presented at the Information and Communication Technology for Social Development International Symposium, Jakarta, Indonesia.

Wagner, D. A., Day, B., James, T., Kozma, R. B., Miller, J., \& Unwin, T. (2005). 
Monitoring and evaluation of ICT in education projects: A handbook for developing countries. Washington, DC: The World Bank.

Weiss, C. (1979). Mobilizing technology for developing countries. Sciences, 203, $1083-$

1089 World Bank. (2001). World Development Indicators. Washington, DC: the Author. 